

\section{Late Stages}

microorganisms

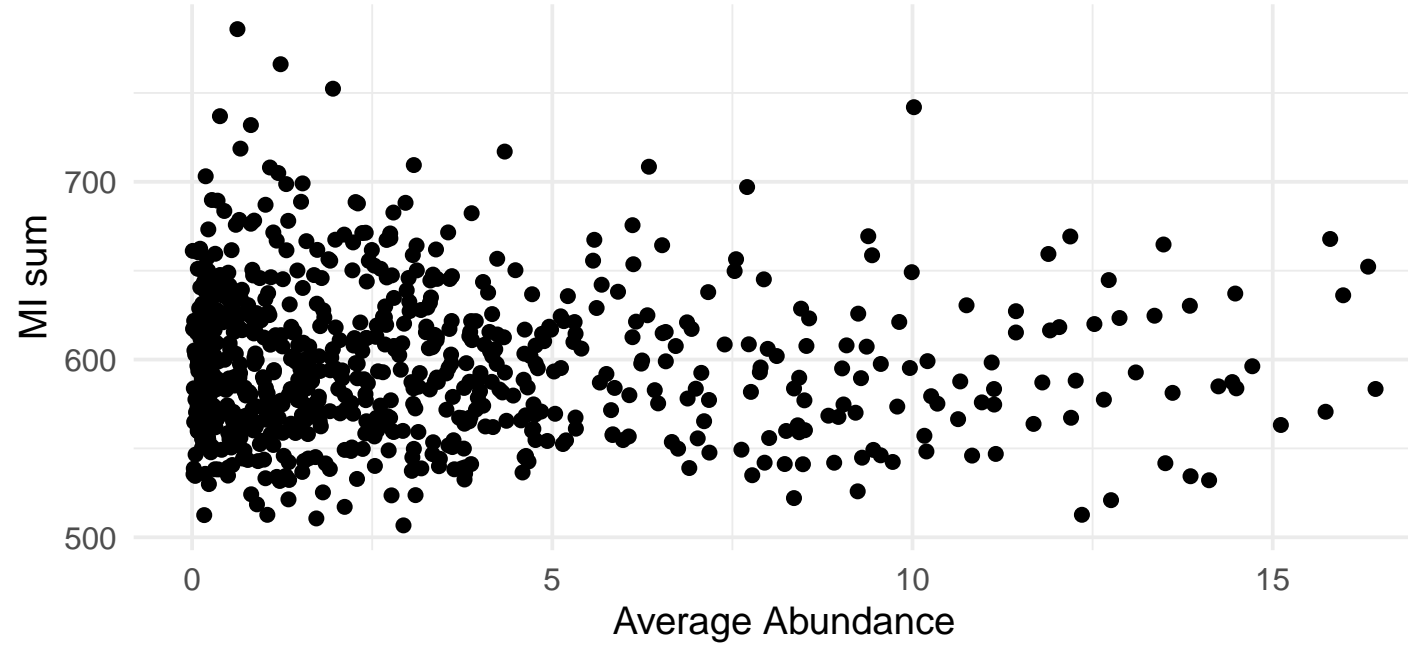




\section{Early Stages}

genes

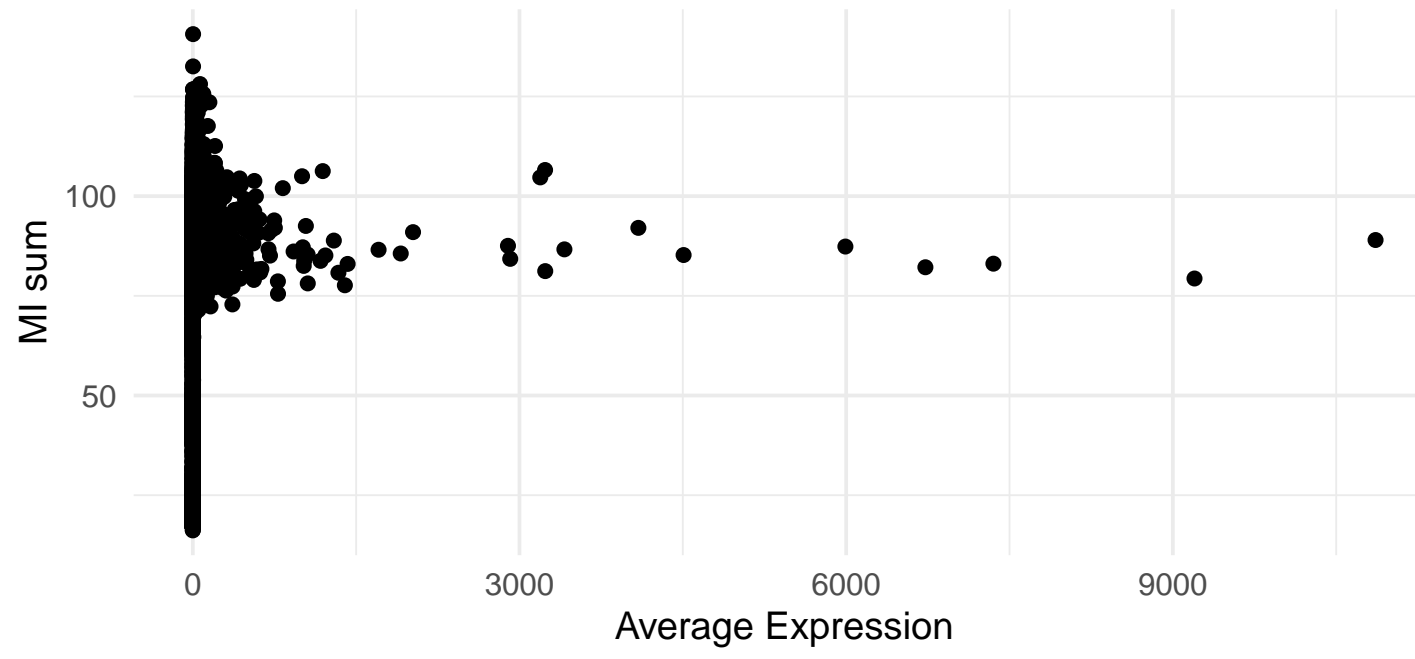




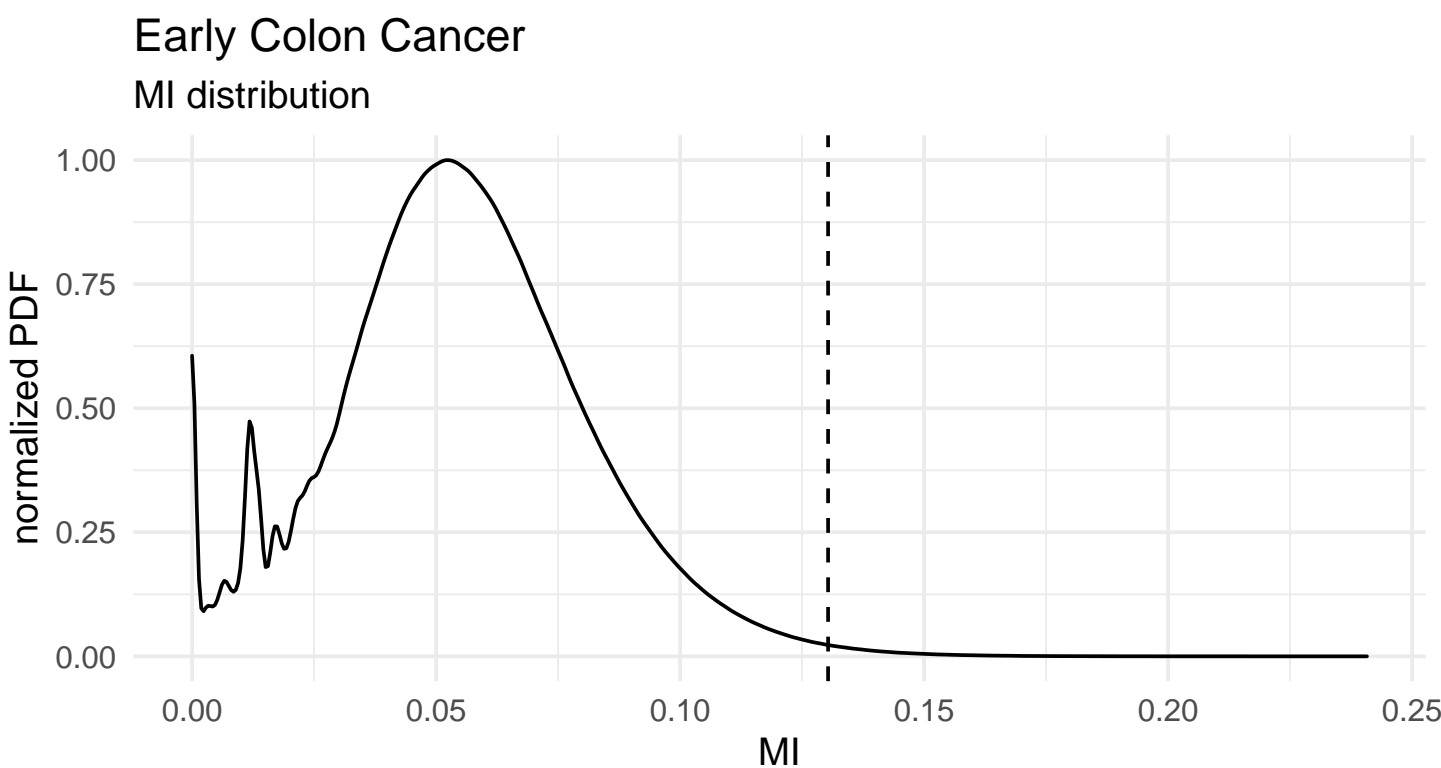




\section{Late Colon Cancer}

MI distribution

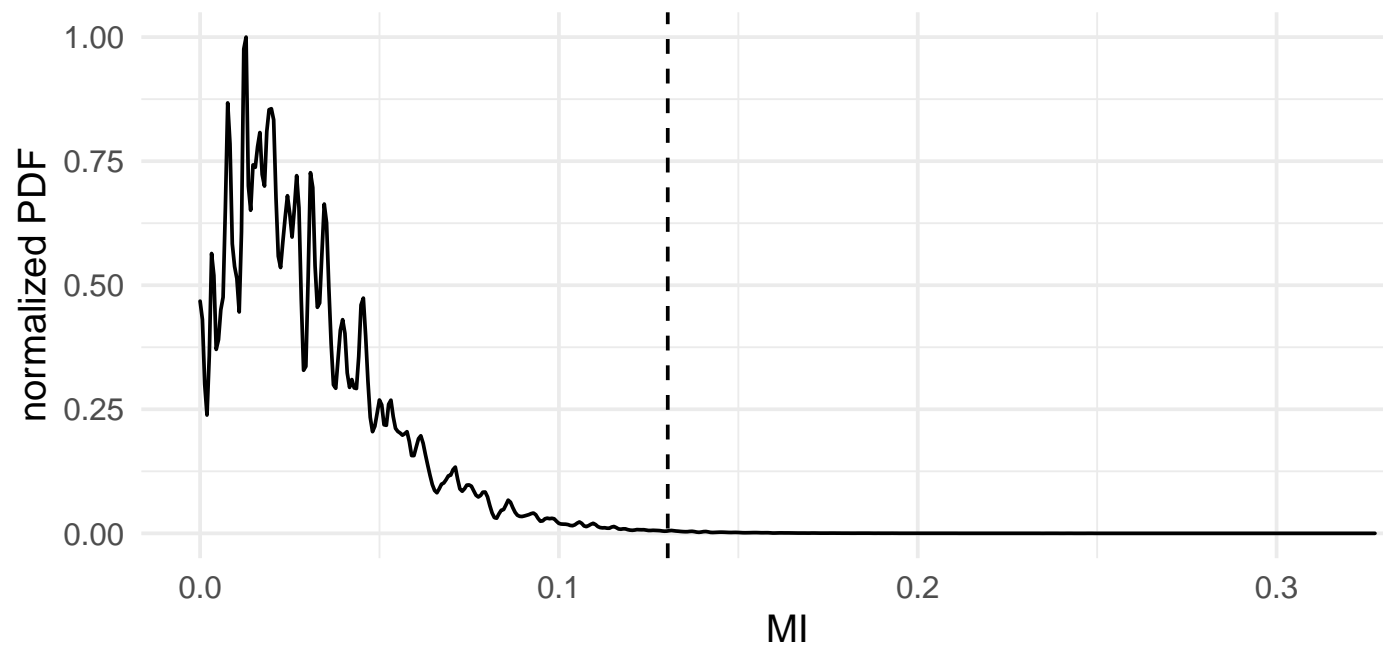

